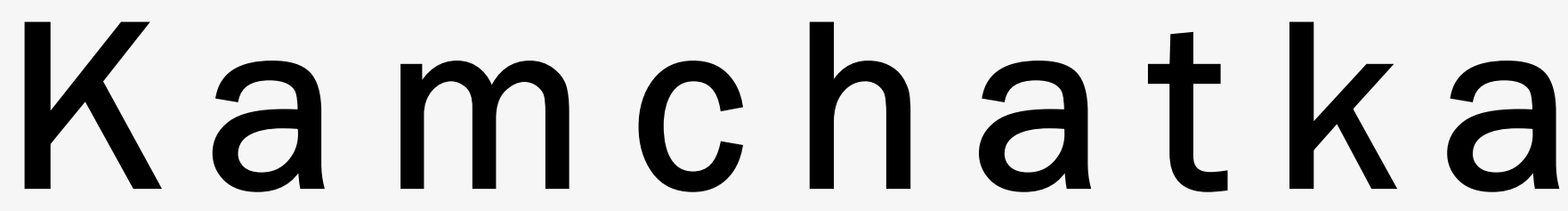

Revista de análisis cultural

N. 15

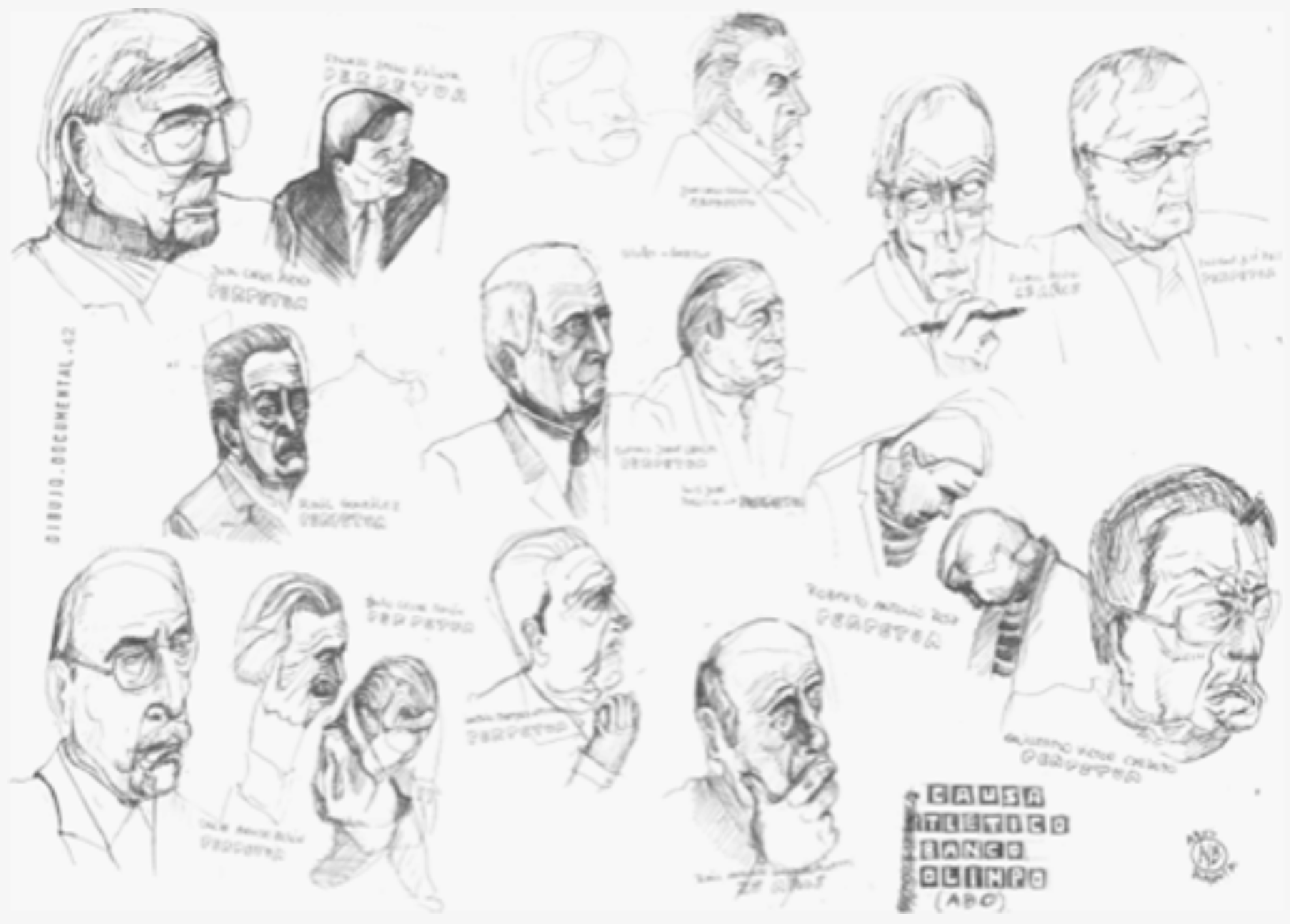

La construcción social de la figura del perpetrador: procesos sociales, luchas políticas, producciones culturales Coordinado por Claudia Feld y Valentina Salvi 


\title{
LA CONSTRUCCIÓN SOCIAL DE LA FIGURA DEL PERPETRADOR: PROCESOS SOCIALES, LUCHAS POLÍTICAS, PRODUCCIONES CULTURALES
}

\author{
KAMCHATKA. REVISTA DE ANÁLISIS CULTURAL 15 (2020) \\ Monográfico coordinado por CLAUDiA FELD Y VALENTINA SALVI \\ Imagen de portada: "Condenados en Causa ABO I". \\ AZUL BLASEOTTO. (http://www.azulblaseotto.blogspot.com/) \\ Dibujo documental in situ y en tiempo real, 2010 Tinta s/papel.
}

VALENTina SAlvi y Claudia FELD. La construcción social de la figura del $5-15$ perpetrador: procesos sociales, luchas políticas, producciones culturales.

I. Conflictos $\mathrm{Y}$ Debates SOCIALES EN TORNO A LA FIGURA DE LOS PERPETRADORES.

PABlo SÁnChez LEÓn. La memoria de los verdugos de 1936 y la cultura del aimpuni(bili)dad en la democracia posfranquista.

F. Miguel De Toro. La exposición Vernichtungskrieg. Verbrechen der Wehrmacht 47-69 1941 bis 1944. El debate sobre los crímenes de la Wehrmacht.

NiKOLINA ZiDEK, Y ANA LJUBOJEVIC. Héroes y criminales: sobre la construcción $71-93$ de criminales de guerra croatas como héroes de la nación.

II. FIGURAS LIMINARES Y RELACIONALES. EL PERPETRADOR EN EL ESPEJO SOCIAL. ANA Lara Ros MatTuro. El soldado que no fue: interrogando el ejército, la obediencia debida y el nunca más.

TERESA BASILE. Padres perpetradores. Perspectivas desde los hijos e hijas de 127-157 represores en Argentina. 
III. MEDIACIONES Y ESCENARIOS PARA LA PALABRA Y LA IMAGEN DE LOS PERPETRADORES.

LYOR ZYLBERMAN. Los victimarios en el cine documental. Una posible taxonomía.

VALENTINA SALVI. Trayectoria, capital e ideología. Las declaraciones de los 193-215 perpetradores en los juicios por crímenes de lesa humanidad en la Argentina.

LORENA VERZERO. Construcción performativa de la autoridad: entramado de 217-241 sentidos en apariciones, imágenes y representaciones de Videla.

VANesa GARbero y Mónica Mercado. El circuito del terror en Córdoba: 243-267 reflexiones sobre la representación de los represores en los sitios de memoria.

IV. EL PERPETRADOR COMO OBJETO DE REPRESENTACIONES ARTÍSTICAS.

MARÍA LUISA Diz. Declaraciones públicas y artes escénicas: la construcción de 271-292 personajes y narrativas de apropiadores y apropiadoras en Teatro x la Identidad (2000-2001).

NADIA MARTín. La figura de Videla como paradigma del terror dictatorial. 293-312 Reflexiones en torno a dos obras tecnopoéticas. 


\section{LA EXPOSICIÓN VERNICHTUNGSKRIEG.}

\section{VERBRECHEN DER WEHRMACHT 1941 BIS 1944. EL DEBATE SOBRE LOS CRÍMENES DE LA WEHRMACHT}

The Vernicbtungskerieg Verbrechen der Webrmacht 1941 bis 1944 exhibition.

The debate on the crimes of the Webrmacht

\section{F. MiguEL DE TORO}

INVESTIGADOR INDEPENDIENTE

info@memoriales.net http://orcid.org/0000-0002-9352-3497

RECIBIDO: 17 DE JUNIO DE 2019

ACEPTADO: 5 DE FEBRERO DE 2020

RESUMEN: Durante décadas el mito de la "Wehrmacht limpia" sirvió a la sociedad alemana como una forma de evitar enfrentarse a los crímenes del Nazismo, impidiendo que los soldados alemanes se viesen implicados en la guerra de aniquilación en el Este, pero evitando también que se representase la imagen del perpetrador. La exposición Vernichtungskrieg. Verbrechen der Webrmacht 1941 bis 1944 (1995-1999) fue la primera ocasión en que la sociedad alemana se enfrentó directamente con esos crímenes, que implicaban a una gran parte de la misma. Y, por primera vez, se ponía rostro a algunos de los perpetradores de los crímenes. La exposición abrió nuevas líneas de investigación para los historiadores sobre la mentalidad de los soldados, fuentes materiales, motivos de los perpetradores, etc. La reacción ante la exposición fomentó un debate historiográfico que ha permitido que se enfrente más abiertamente con su pasado, un paso más en la Vergangenheitsbewältigung sobre el pasado nazi. La investigación sobre la identidad social de los perpetradores se acaba de iniciar, pero las narrativas están desarrollándose de forma similar a la del Holocausto a mediados de los 1970. La controversia demostró, una vez más y como señala Nolte, que el pasado "no ha pasado".

PALABRAS CLAVE: perpetrador, Wehrmacht, Vernichtungskrieg, guerra de aniquilación, Segunda Guerra Mundial, Nacionalsocialismo, Alemania, Holocausto.

ABSTRACT: For decades the myth of the "clean Webrmacht" served German society as a way to avoid confronting the crimes of Nazism, preventing German soldiers from becoming involved in the annihilation war in the East. But also preventing the image of the perpetrator from being represented. The Vernichtungskrieg exhibition. Verbrechen der Webrmacht 1941 bis 1944 (1995-1999) was the first time that German society directly faced these crimes, which involved a large part of it. And, for the first time, put face to some of the perpetrators of the crimes. The exhibition opened new lines of research for historians on the mentality of the soldiers, material sources, motives of the perpetrators, etc. The reaction to the exhibition fostered a historiographic debate that has allowed it to face its past more openly, one more step in the Vergangenheitsbewältigung about the Nazi past. The investigation into the social identity of the perpetrators has just begun, but the narratives are developing in a similar way to that of the Holocaust in the mid-1970s. The controversy demonstrated, once again and as Nolte points out, that the past "has not past".

KEYWORDS: perpetrator, Wehrmacht, Vernichtungskrieg, war of annihilation, World War II, National Socialism, Germany, Holocaust.

“La exposición Vernichtungskrieg. Verbrechen der Wehrmacht 1941 bis 1944. El debate sobre los crímenes de la Wehrmacht”. 


\section{INTRODUCCIÓN}

Durante el siglo XX Alemania vio una convulsión tras otra: "la ruptura con la civilización" (Diner, 1988) en 1933, la devastación de dos guerras mundiales, la ocupación extranjera, la Guerra Fría y una reunificación pacífica. Pero el temor de los alemanes al pasado nazi se aprecia en el vacío y los eufemismos incómodos que aún usan muchos para referirse a él: "aquellos tiempos" o "nuestro difícil pasado" 1.

Tras la reunificación, los alemanes se vieron envueltos en un debate sobre el pasado como no lo habían estado anteriormente. Muchas de las visiones presentadas del Nazismo tras 1990 deben entenderse como un resultado de la reunificación, y no como una contradicción de la misma. Esto se explica porque las visiones del pasado salieron del ámbito académico al público mediante exposiciones, libros, debates y películas, que fueron quebrando las imágenes y mitos típicos de Alemania, que nunca habían atraído tantas miradas públicas o el interés de los medios de comunicación ${ }^{2}$. Sin duda parecía que sólo tuvieron ese efecto porque era el momento adecuado para su aparición.

Autores como Bill Niven (2002) han señalado que el final de la división geopolítica de Alemania creó las precondiciones ideales para una mayor apertura y para la persistente confrontación con el pasado, que tenía también una dimensión política y legal, aunque la auténtica novedad fue la inclusión del debate público. Se inició una presentación del pasado más inclusiva de lo que había sido hasta los 1990: ahora existía una amplia conciencia de la verdadera extensión de la criminalidad nazi y de los grupos de víctimas, aunque siempre había ámbitos del Nazismo, como de cualquier otro pasado, que necesitan ser reconsiderados y reanalizados.

Pero, ¿cómo incorpora un estado los crímenes en su paisaje memorial? ¿Bajo qué auspicios morales, qué leyes, recuerda una nación su propia barbarie? Y, sobre todo, ¿cómo incorporar la figura del perpetrador en su memoria social? (Young, 1993: 22).

Si el pasado funciona como una forma de proporcionar significado al presente, Alemania no se embarcó voluntariamente en el "ajuste de cuentas" con su pasado tras el final de la guerra: fueron los Aliados los que "estimularon" ese proceso 3 . Pronto se hizo obvio que Alemania debía

\footnotetext{
${ }^{1}$ Este artículo es una versión revisada y ampliada de una ponencia presentada para el VI Encuentro Internacional de Jóvenes Investigadores en Historia Contemporánea, celebrado en Zaragoza, entre el 6 y el 8 de septiembre de 2017, titulada "La Wehrmacht y la historiografía. El debate sobre los crímenes de la Wehrmacht: Vernichtungskrieg. Verbrechen der Wehrmacht 1941 bis 1944". Agradezco los comentarios realizados por los participantes en el Congreso, por su lectura y sugerencias.

2 Sin duda, se dieron algunas excepciones, como la cobertura mediática a juicios a los perpetradores, o la emisión de la serie televisiva Holocausto.

3 Después de la caída del régimen de Hitler, el proceso de Entnazifizierung (desnazificación) tenía la intención de erradicar el nazismo. Fue una tarea inmensamente complicada para los Aliados. El proceso se desarrolló lentamente y con el inicio de la Guerra Fría, en algunos casos, aquellos que merecían castigo pudieron escapar (Borgstedt, 2009: 87-88). Esto llevó a Karl Jaspers a formular su teoría sobre la “culpa colectiva”. Jaspers se volvió contra el espíritu de la represión y también exigió que todos cuestionen su responsabilidad. Al mismo tiempo, impugnó la tesis de la Kollektivschuld, señalando: "[...] no tiene sentido acusar a un pueblo en su conjunto de un delito. Solo el individuo es un criminal. [...] Tampoco tiene sentido acusar moralmente a un pueblo en general [...]. Solo el individuo, nunca un colectivo, puede ser juzgado moralmente" (Jaspers, 1979: 38).
} 
redefinir su identidad nacional, a la luz de su pasado, para reincorporarse a la comunidad de naciones democráticas.

La Alemania dividida mantuvo una difícil relación con su pasado (de Toro, 2009: 87-106; 2016: 281-305). En este proceso ha habido diferentes "catalizadores" que han activado la confrontación, algunos de la propia sociedad alemana, otros desde el exterior, y algunos de los impulsos más fuertes procedían de ámbitos mediáticos, generalmente relacionados con aniversarios. Grossman se refiere a estos catalizadores como "momentos del Holocausto" y observó que la historia alemana estuvo "sembrada" de ellos. Sin embargo, fueron algo más que meros momentos y la imagen de "olas" de Meier parece más apropiada, ya que implica una serie de controversias que literalmente alteran el statu quo que la sociedad ha mantenido entre una ola y otra (Grossman, 2000: 89-129; Meier, 2001: 46).

Durante la postguerra, los debates de memoria han sido, por definición, plurales y conflictivos, formando una parte significativa de la autoconciencia nacional alemana: la controversia Fischer (1961-64), la Historikerstreit (1986-87), la Neue Wache (1993), el debate Goldhagen (1995), sobre la Wehrmachtsausstellung (1995-99), el debate Walser-Bubis (1998-99) o la construcción del memorial del Holocausto (1993-2005), etc.

En todos estos debates estuvieron presentes algunos elementos esenciales que se repitieron: el pasado y su representación en el presente, el papel de los historiadores, la interacción entre memoria pública y privada y el impacto de concepciones del pasado en la identidad nacional. En este contexto, el reconocimiento de los crímenes fue relativamente sencillo, pero no así la identificación de los perpetradores o los debates sobre culpa y justicia 4 . Aunque los crímenes y las víctimas estaban siendo redescubiertos durante los 1980, los perpetradores aún se mantuvieron en una relativa oscuridad.

El término "perpetrador" ha asumido un gran impulso, en tanto que ha provocado controversia desde mediados de los años 1980. Las razones para este creciente interés son numerosas. En parte surgen del hecho de que entre las tres categorías usadas para analizar el papel de los individuos durante el Holocausto - perpetradores, víctimas y testigos-, la categoría del perpetrador había sido la menos analizada hasta aquellos momentos. Al mismo tiempo, se refiere a un aspecto esencial de la vida humana: la de aquellas personas que en situación de conflictos toman papeles variados, a menudo activos.

Con cada nuevo debate el trabajo de los historiadores se hizo más controvertido, debido también al papel de los medios de comunicación. Por ejemplo, la controversia sobre la exposición de la Wehrmacht es casi impensable sin su participación, abriendo nuevos canales de debate para que los historiadores alcanzasen audiencias más amplias. Pero también han contribuido a la construcción de un paisaje memorial nacional, desmantelando pieza a pieza los tabús sobre el Nazismo.

\footnotetext{
4 Esto queda evidenciado con las escasas condenas que sufrieron los perpetradores en la RFA: de poco más de 170.000 instrucciones, sólo hubo 6.700 condenas, la mayoría de ellas a penas bastante leves. También es un reflejo de las dificultades de la judicatura alemana para perseguir a los culpables en los años 1970-1980.
} 
Las políticas de la derecha alemana y su fracaso a la hora de enfrentarse al papel del perpetrador nazi son aspectos del mundo político alemán que han venido marcados por la presencia de nazis en diversas administraciones gubernamentales.

El concepto de la "sociedad de perpetradores" (es decir, prácticamente toda la sociedad alemana de postguerra) no proporcionaba un marco de interpretación suficiente para la investigación y descubrimiento del papel de los perpetradores en los 1960-1970, cuando comenzaron a reconocerse las amplias implicaciones de los crímenes del régimen. Comenzó el reconocimiento de que muchos más de los que habían sido juzgados en Nürnberg habían tenido responsabilidades por los crímenes.

Las exposiciones sobre los crímenes de la Wehrmacht que tuvieron lugar a finales de los años noventa y principios de la década del dos mil marcaron un punto de inflexión de gran importancia. El cambio se vio en el momento en que la sociedad alemana se vio enfrentada abierta y públicamente con los crímenes del Nazismo y la implicación del conjunto de la población en esos crímenes. Centraremos, pues, nuestro análisis en el impacto que estas exposiciones tuvieron en la imagen social de los perpetradores.

\section{EL MITO DE LA WEHRMACHT "LIMPIA"}

Tras la Segunda Guerra Mundial era imposible reconstruir la nación y la sociedad alemana a menos que se definiese a los criminales nazis dentro de un espacio extremadamente limitado, evitando que el conjunto de la sociedad quedase incorporada a esa imagen. Mientras la confrontación de la sociedad con el pasado avanzaba trabajosamente, la confrontación con el pasado de la Webrmacht se convirtió en un tabú, sobre todo cuando pasó a formar el núcleo esencial del futuro Bundeswehr. Si la implicación de los soldados en los crímenes contra la población civil ya era perturbadora, la asociación del ejército con el Holocausto era aún más preocupante, porque era el epítome del mal y, por tanto, debía ser adscrito a perpetradores que quedaban estrictamente separados del resto de la población. Si se entrelazaba el Holocausto con la Webrmacht se borraban esas distinciones entre alemanes y nazis, una distinción que aún se desvanecería más con la publicación del libro de Browning, en 1992.

Como con otros ámbitos historiográficos a partir de los 1970, que comenzaron a formarse en una dinámica de "abajo a arriba", también comenzó a aplicarse la Alltagsgeschichte a la Webrmacht, y varió sustancialmente la aproximación tradicional de la historia militar y su foco en las tácticas y estrategias. De esta investigación comenzó a emerger una imagen que contrastaba con el mito de la "Wehrmacht limpia", una organización que se había mantenido impermeable a la ideología nazi y que había luchado de forma honorable y justa, sin implicarse en los crímenes. Aparecieron nuevos intentos de comprender a los individuos más que a los sistemas, ver la ideología en su contexto, más que como una entidad abstracta para desentrañar las complejidades de la ideología humana (Bergmann y Schörcken, 1982; Broszat y Fröhlich, 1987; de Toro, 1996; Kershaw, 1983).

Hasta mediados de los 1980, la memoria del Holocausto estuvo centrada en las víctimas y su experiencia durante la guerra, y se dedicó mucha menos atención a los textos que trataban con el punto de vista de los perpetradores del Holocausto. Además, la mayoría de los textos escritos 
desde la perspectiva de los perpetradores disponibles habían sido trabajos de ficción literaria, memorias personales o retratos individuales de algunos responsables ${ }^{5}$.

Sin embargo, hubo una evolución en la representación de la Segunda Guerra Mundial y la Shoah. Wieviorka señala que el juicio de Eichmann, en 1961, "marca un verdadero giro en la aparición de la memoria del genocidio", en tanto que la figura del ejecutor y el testimonio del perpetrador se convirtió, por primera vez, en el centro de atención durante un juicio ampliamente emitido y comentado (Wieviorka, 1998: 81).

A comienzos de los 1980, los historiadores podían afirmar correctamente que aún "no existe un estudio adecuado sobre los perpetradores del Holocausto" (Friedlander, 1983: 155). Especialmente en Alemania, la Täterforschung (la investigación del perpetrador) comenzó a crecer exponencialmente a partir de finales de esa década, en tanto que las generaciones de postguerra, finalmente, comenzaron a investigar las cuestiones que habían temido preguntar a sus padres y abuelos (Paul, 2002: 13-90). Longerich ha definido el objetivo de esa investigación como "ofrecer explicaciones para el crimen del siglo" (Longerich, 2007: 7). En sólo unos pocos años hemos llegado a una situación en la que en lugar de ignorancia y estereotipos hemos alcanzado una amplitud de detalles que es casi imposible hacer cualquier tipo de afirmación general sobre los perpetradores: tan variada y heterogénea es esa investigación.

El debate fue iniciado por el trabajo de Browning (1992) y la exposición de la Wehrmacht, tras 1995. Browning describió las actividades del Batallón 101 de la Policía del Orden en Polonia, mostrando cómo un grupo de hombres que no eran parte de las SS y que procedían de orígenes normales se convertían en asesinos de masas, como parte de un proceso de enfrentamiento cara a cara con las matanzas en la Europa oriental. Aunque no negaba que la ideología fue importante, también mostraba que los hombres de esa unidad no eran fanáticos nazis sino, más bien, hombres que se transformaron en base a razones de lo más mundano. Browning finalizaba sus reflexiones con la ahora famosa cuestión: “isi los hombres del Batallón de Policía 101 de la Reserva pudieron convertirse en asesinos bajo tales circunstancias, qué grupo de hombres no lo haría?” (Browning, 1992: 189).

Desde entonces, la investigación sobre los perpetradores ha estado buscando la respuesta a esa cuestión, examinando las circunstancias y, especialmente, las motivaciones ideológicas de esa transformación. La literatura social-psicológica señala que los perpetradores del Holocausto (igual que los perpetradores de otros genocidios) no eran predominantemente sádicos, sino personas "normales" en situaciones inusuales.

Lo que los historiadores añaden a la explicación es el marco de esas situaciones inusuales y cómo se desarrollaron. Es decir, ponen en juego los factores culturales y sociales que influyeron en las situaciones en las que los perpetradores se encontraron ellos mismos. Aunque muchos perpetradores habían sido personas estables, en su mayor parte habían vivido los hechos de la Primera Guerra Mundial y sus consecuencias, las crisis de los años de la República de Weimar, el Nazismo, y se vieron sujetos a la dura propaganda antisemita nazi. Sin embargo, la otra cara de la

\footnotetext{
5 Por ejemplo: Sereny, Gitta (2009). Desde aquella oscuridad: conversaciones con el verdugo: Franz. Stangl, comandante de Treblinka. Barcelona, Edhasa; Broszat, Martin (ed.) (1998). Kommandant in Auschwitz: Autobiographische Aufzeichnungen des Rudolf Hößs. Múnich: dtv Verlagsgesellschaft.
} 
moneda es lo que Naimark nos recuerda, en referencia a los soldados y oficiales alemanes: "Había pocos 'hombres ordinarios' entre ellos; o mejor, los soldados alemanes ordinarios tendían a tener fuertes puntos de vista nazis, incluso cuando no eran ellos mismos nazis" (2007: 274). Probablemente, la prueba más sorprendente de la "normalidad" es su estabilidad mental tras la guerra. "Con pocas excepciones, los asesinos se salvaron de los síntomas del trauma de por vida que estuvieron y se mantienen como un terrible legado de las víctimas supervivientes" (Kwiet, 2001: 80).

Los académicos descubrieron una Wehrmacht que no sólo había colaborado con el régimen en su guerra racial, sino que ayudó directamente en el exterminio de grupos raciales y políticos perseguidos por el régimen. Este cambio de perspectiva provocó tensiones en la dicotomía del "buen alemán" versus los "malvados nazis", que se había mantenido desde el final de la guerra.

El impacto político de esos trabajos es, por supuesto, inmenso, ya que no sólo reclamaba una profunda reevaluación del significado e implicaciones del régimen nazi para la sociedad durante y tras la guerra, también desacredita algunas de las teorías más claramente sostenidas sobre la capacidad de la Alemania de postguerra de 'llegar a asumir' su pasado (Bartov, 1999: 13).

Aunque la Wehrmacht fue oficialmente disuelta tras la capitulación, esto no supuso el final de su historia, sino que consiguió lo que algunos consideran su última victoria: la lucha para preservar su imagen y reputación, a los ojos del público alemán e internacional. El mito se mantuvo vivo, y aún lo está entre algunos sectores: dentro del Bundeswehr, por ejemplo, la Webrmacht continúa proporcionando una referencia y modelo, aunque oficialmente no se mantenga esa conexión.

El resultado fue que el Holocausto, junto al asesinato de otros "enemigos" (reales o imaginarios), incluso cuando entraban gradualmente en la historiografía de la guerra, raramente estuvo asociado con el contexto militar, o lo hicieron de forma distorsionada. Además de que los alemanes fuesen reacios, por razones obvias, a asociar la Wehrmacht con el Tercer Reich y sus crímenes, también los Aliados fueron reacios a ver el Holocausto como un elemento central del conflicto bélico: una cosa era acusar y condenar a altos dirigentes del régimen y otra muy diferente identificar a la Webrmacht con una organización criminal. De hacerlo, ambos estados alemanes se hubiesen convertido en unos incómodos aliados en la Guerra Fría: hubiera significado una acusación de culpa colectiva para Alemania. La idea de que la Wehrmacht se hubiese visto implicada en los crímenes se convirtió en un anatema porque hubiese sido necesaria una amnistía general (legitimando así la noción de crímenes sin castigo) o la renuncia completa a la posibilidad de resurrección de alguna forma de identidad nacional ${ }^{6}$. Ninguna de estas opciones era realista, especialmente frente al deterioro de las relaciones internacionales en los años 1950-1960.

Hasta finales de los 1960, el ejército alemán fue representado como una organización de profesionales que había luchado con tenacidad y competencia, completamente ajeno a los crímenes nazis. Esta visión se había extendido gracias a las memorias de los veteranos, la

\footnotetext{
6 Entre 1935-1945, aproximadamente 20 millones de personas sirvieron en la Wehrmacht, creándose un auténtico "ejército popular", de forma que virtualmente un padre o un hijo de cada familia había participado en la maquinaria militar, un hecho muy significativo para la creación del mito (Kroener, 1990).
} 
literatura, el cine y la sociedad en general, pero también fue la línea oficial del gobierno germanooccidental y fue una noción que los académicos alemanes raramente desafiaron (Abenheim, 1988; Bartov, 1985: 1-4; Fehrenbach, 1995; Large, 1996). Esta idea fue fruto tanto de las políticas de memoria oficiales como del paso de muchos oficiales de la Wehrmacht al Bundeswehr.

Los historiadores occidentales aceptaron este punto de vista porque su perspectiva de la guerra se basaba en el conflicto en el Oeste donde, salvo algunos momentos puntuales, ambos bandos se habían adherido a los convencionalismos de la guerra, al contrario de lo que había pasado en el Este.

La experiencia personal dominó la imagen que muchos tenían de la Webrmacht al final de la guerra, una imagen que se vería casi inalterada hasta los 1970-80, cuando comenzó la publicación de numerosos estudios que desafiaban el mito. La publicación en 1965 de Anatomie des SS-Staates, que incluía un análisis de la "Orden de los Comisarios", anunciaba el comienzo de los análisis sobre las actividades criminales de la Webrmacht en su campaña en el Frente del Este (Jacobsen, 1965: 163-283). Esto fue seguido en 1969 por un estudio de las políticas de adoctrinamiento ideológico en la Wehrmacht, o sobre la colaboración de los Einsatzgruppen y la Wehrmacht en 1981. Streit y Streim comenzaron a analizar el destino que habían sufrido los prisioneros de guerra soviéticos y una serie de monografías del Militärgeschichtliches Forschungsamt, fundado por el Ministerio de Defensa, cubrían la guerra de exterminio en el Este y los crímenes de guerra en Yugoslavia, Grecia e Italia. Asimismo, la investigación de Manoschek descubría los crímenes en Serbia (Krausnick, 1981; Messerschmidt, 1969; Michalka, 1989; Militargeschichtliches Forschungsmat, 1990; Streim, 1981; Streit, 1978; Wegner, 1997; Wette, 1992; Wette y Ueberschar, 1992). Estas investigaciones comenzaron a mostrar una imagen de la Webrmacht que contradecía la leyenda, aunque siguió sin desafiarse abiertamente. En 1985 Hillgruber señalaba por primera vez que la decisión de asesinar a los judíos debía considerarse como una campaña genuina del conflicto, y no como un hecho aislado, porque a ojos de gran parte de los líderes nazis la guerra había servido como un medio para alterar el balance racial de Europa (Hillgruber, 1985). Ueberschar señalaba que las órdenes militares revelaban un alto grado de involucración del ejército en el exterminio, que la Wehrmacht fue permeada por la ideología y propaganda sobre la aniquilación del "bolchevismo judío" y que los mandos no tuvieron escrúpulos para cooperar en la campaña de exterminio (Ueberschar, 1995: 50).

Las "historias locales" se esforzaban en penetrar en los cambios sociales y políticos, centrándose en una comunidad limitada, y eso también se reflejó en los estudios sobre unidades militares individuales, focalizándose en los escalones más bajos, conscientemente dirigidos a investigar la extensión en la que las tropas fueron influenciadas por los argumentos ideológicos y llevaron a cabo órdenes criminales.

En el "debate de historiadores" de mediados de los 1980, la Historikerstreit, el sector de historiadores conservadores, intentó presentar la guerra en el Este como una lucha desesperada contra un enemigo invasor que amenazaba con destruir no sólo a Alemania, sino al resto de la civilización occidental (Bartov, 1996; Hillgruber, 1986). Pero no introdujo evidencias nuevas ni interpretaciones originales, sino que fue un debate político e ideológico sobre el significado del pasado y la forma de influir en el presente (Evans, 1989; Maier, 1988). A pesar de un cierto cambio de rumbo con la historia social, los historiadores siguieron prestando una limitada 
atención al ejército (Bartov, 1994: 41-66), y los únicos que analizaban los archivos del ejército eran los historiadores militares, que no siempre buscaron los aspectos más oscuros de esa historia.

Esta literatura ha tenido un efecto importante en el academicismo sobre el Tercer Reich y se ha convertido en un elemento sine qua non para cualquier investigación sobre el período. El enorme trabajo archivístico en el que se basaban esos estudios barrió muchos de los supuestos sobre la Webrmacht. No sólo reclamaban una reevaluación profunda del significado e implicaciones del régimen para la sociedad durante y tras la guerra, sino que también desprestigiaba algunos se los mitos más extendidos sobre la capacidad de la Alemania de postguerra de "asumir" su pasado.

Entre los hallazgos de estos estudios se señalaba que los soldados fueron, sin duda, expuestos a los masivos esfuerzos adoctrinadores de las autoridades militares. Pero también se hacía referencia al adoctrinamiento ideológico que ya había sido diseminado entre la juventud antes de su reclutamiento (en la escuela, las Juventudes Hitlerianas y el Frente del Trabajo) y que respondía a prejuicios ya existentes. De ahí que la propaganda destinada a las tropas fuese tan efectiva al moldear los puntos de vista raciales. Bajo la influencia de esa ideología deshumanizante y una guerra brutal, las tropas se vieron involucradas en crímenes contra soldados y población civil.

Todos estos factores unidos llevaron a lo que he denominado la 'barbarie de la guerra' en el frente oriental que tuvo como consecuencia la devastación de grandes extensiones de tierra, especialmente en las zonas ocupadas de la Unión Soviética, y causó la muerte de millones de personas civiles y prisioneros de guerra, ya fuese por asesinato o hambre, las epidemias, la exposición a los elementos y la explotación económica. En otras palabras, tanto desde el punto de vista de los generales y de la de las tropas, la campaña en el Este se llevó a cabo como una guerra de aniquilación (Bartov, 2000b: 169).

Bartov ha señalado que la pervivencia de la leyenda fue el resultado también de la vacilación de los historiadores para ahondar en él. Aquí jugaron un papel activo las "políticas de amnesia" de la RFA, como ha señalado Frei, durante la primera fase de la postguerra (2002: 62). "La amplia atención pública prestada a los pocos criminales de guerra condenados en las campañas de amnistía de aquellos años reveló algo sorprendente sobre la mentalidad pública” (Bartov, 2000c: 422).

La excesiva compartimentación disciplinaria por la que los historiadores estudiaban temas relacionados con la guerra, a la que el Holocausto parecía no pertenecer, mientras los historiadores del Holocausto se abstenían de estudiar la relación de la Webrmacht y se centraban en los mecanismos directamente relacionados con el genocidio, se ha mantenido en algunos sectores.

Con el final de la división alemana y de una amenaza "real" por parte de la Europa comunista, la necesidad de adaptar la historia de la Webrmacht a las exigencias de la Guerra Fría fue desapareciendo: por tanto, la confrontación nacional con los crímenes ya era posible, y se abrió paso progresivamente. 


\section{LA WEHRMACHTSAUSSTELLUNG}

Bajo el concepto de Wehrmachtsausstellung (exposición de la Wehrmacht) se engloban las dos exposiciones sobre los "crímenes de la Webrmache" (1995-1999 la primera, y 2001-2004 la segunda). La primera de ellas provocó una de las controversias públicas más importantes en la historiografía alemana, mientras que la segunda quedó más diluida por su reformulación. La controversia se inició cinco años después de la reunificación y coincidió con el 50 aniversario del final de la guerra. La exposición impulsó la discusión entre historiadores y otros intelectuales, pero también políticos, medios de comunicación y el público general. Se rompieron tabúes dentro de cada grupo social, especialmente sobre la autocomprensión política o dentro de la memoria popular del pasado, planteó nuevas cuestiones y, en diversos grados, sirvió para incitar nuevos análisis. Estos debates públicos afectaron profundamente a la memoria alemana, tanto colectiva como personal.

Lo que se apoderó de Alemania entre 1995 y 1999 se puede considerar como el debate historiográfico más mediático hasta y desde entonces: nunca antes una controversia había durado tanto; nunca antes una exposición histórica había atraído a casi un millón de visitantes; nunca se había implicado a casi todas las facetas de la sociedad; nunca un evento histórico había incitado tal agitación de extrema derecha (Knäpple, 2009: 289). Nunca un acontecimiento histórico había provocado a diversas generaciones como la Wehrmachtsausstellung: su impacto sorprendió incluso a sus creadores (Manoschek, 2002: 67).

La Wehrmachtsausstellung afectó a la conciencia histórica de los alemanes post-reunificación, fortaleciendo la convicción de muchos de que Alemania no podría participar de nuevo en una guerra, ni siquiera como parte de una alianza militar o en una fuerza de paz. Este tema, además, se integró en los debates sobre la participación alemana en diferentes misiones internacionales en el conflicto de Yugoslavia.

Las consecuencias formaron parte de una nueva identidad nacional, más profundamente de lo que lo habían hecho otras anteriores, pero no fue sólo una controversia sobre identidad nacional, sino sobre el honor y la integridad personal de aquellos que habían servido en el ejército de Hitler, porque implicaba también que muchas familias habían conocido los hechos del Frente Oriental, a través del correo y las fotos que recibían del frente (algunas de las cuales fueron parte de la exposición) y las historias que explicaban los soldados de permiso7. Se ampliaba así enormemente el círculo de los perpetradores y de aquellos que habían conocido la existencia de los crímenes.

La exposición tenía un estilo propio en su forma de "desmitologizar" el papel de la Webrmacht. Su sección inicial ilustraba un punto de vista acrítico, heroico, de la Webrmacht, tal como se había plasmado en la postguerra. Las discusiones espontáneas provocadas por la exposición fueron contrarrestadas por las más formales en la tarima pública. Wette señala que el mito fue usado como una imagen positiva que sirvió durante la fundación del nuevo Bundeswehr,

\footnotetext{
7 Además de los canales oficiales, circulaban una gran cantidad de noticias informales que pasaban a los civiles en Alemania. Los soldados hablaban de sus propias experiencias a otros soldados y, a pesar de la censura militar, las cartas que enviaban a casa también extendían las noticias. En muchas de esas cartas queda clara la efectividad de la propaganda y el conocimiento común de que los judíos estaban siendo asesinados (Manoschek, 1995: 182).
} 
que no sólo incorporó a muchos oficiales y soldados de la Wehrmacht, sino también algunas de sus tradiciones (1998: 129).

Sólo era un esfuerzo entre otros muchos para reconocer los horrores del genocidio, un proceso para el que los alemanes habían encontrado una palabra que daba al tema una cierta gravedad: Vergangenheitsbewältigung (confrontación o superación del pasado, una formulación ambigua y, por tanto, controvertida). Pero difería de otros muchos esfuerzos que mostraban los horrores del pasado nazi, porque no se centraba exclusivamente en las víctimas o en el aparato de exterminio "clásico", sino que mostraba un elemento hasta entonces ignorado: la Wehrmacht como perpetradora, como parte del aparato de exterminio.

El trabajo fue concebido y realizado por el Hamburger Institut für Sozialforschung, una organización independiente, financiada de forma privada, fundada y dirigida por Reemtsma. Sus principales organizadores fueron el propio Reemtsma, el historiador Manoschek y el historiador y productor de películas Heer.

Metodológicamente, la Wehrmachtsausstellung introdujo nuevos elementos en el discurso y la representación del Holocausto. La exposición itinerante constaba de más de un millar de fotografías inéditas, de pequeño formato, principalmente tomadas por amateurs y contextualizadas con textos apropiados. El poder visual de la exposición abrumaba también por el escaso material textual que acompañaba a las fotos. La mayoría de ellas procedían de archivos de la Europa oriental y Rusia; otras imágenes procedían de álbumes fotográficos familiares y de cartas que los soldados habían enviado a casa y que habían estado olvidadas durante décadas. Aunque los perpetradores habían estado archivando las evidencias durante casi cincuenta años, para comienzos de los 1990 los documentos y fotografías estaban circulando más libremente dentro de las familias y la sociedad.

Se dividía en tres partes: la ocupación de la Rusia Blanca entre 1941-44; los asesinatos de población civil durante la lucha contra los partisanos en Serbia hasta 1941 y las prácticas de aniquilación del Sexto Ejército, en su avance hacia Stalingrado en 1942.

Las imágenes describían escenas de humillación de judíos, desalojos, fusilamientos, fosas comunes, ahorcamientos de civiles, prisioneros demacrados y tropas alemanas observando, algunos soldados posando con los cuerpos, otros participando activamente. Las imágenes transmitían el absoluto desprecio por la vida humana y la enorme magnitud de los crímenes contra la humanidad que había caracterizado la guerra de aniquilación en el Este.

Debido a su origen y contenido, no es sorprendente que el impacto emocional de la exposición fuese tan poderoso para el observador. Algunos visitantes usaban lupas, temiendo reconocer a un familiar en las fotos, como así sucedió ${ }^{8}$. La fuerza visual de las imágenes conmocionaba, horrorizaba o enfurecía de una forma que el mero contexto textual no podía proporcionar. La disposición de los paneles, en forma de Cruz de Hierro, exacerbó aún más la naturaleza controvertida de la exposición y enfureció especialmente a los veteranos, ya que ese

\footnotetext{
${ }^{8}$ Una persona que se reconoció a sí mismo como un observador en una escena de fusilamiento de civiles demandó a Heer por "mancillar su honor" (Hamburger Institut für Sozialforschung, 1999: 186).
} 
símbolo tenía una larga tradición en las fuerzas armadas alemanas para recompensar el valor en combate?.

La exposición rompía con el mito popular de una minoría que había cometido los crímenes del Tercer Reich, mientras la mayoría de los alemanes fueron víctimas de Hitler: la estricta división entre alemanes y nazis y que el Holocausto estaba confinado únicamente a los campos de concentración desaparecía, evidenciando que también tuvo lugar en los territorios orientales ocupados, en campo abierto, de forma pública.

En Alemania y Austria la población comenzó a observar detenidamente las imágenes: eran soldados mostrando, sin reparo, las atrocidades. Contra el trasfondo crudo de la guerra de aniquilación que se evocaba, el marco tradicional de comprensión del Holocausto se transformaba en algo claramente visible y público. Las atrocidades tenían una cierta característica universal de deshumanización que hasta entonces se había mantenido en la "privacidad" de los campos de concentración.

La intención no era sólo promover el debate sobre la relación de la Webrmacht con el genocidio, sino también contribuir a la discusión sobre la barbarie de la guerra en tiempos modernos, a través de la revisión, cincuenta años después, de algunos aspectos de la violencia del siglo XX. Otra intención era desvelar la naturaleza precisa de la organización que había sido forzada a capitular en mayo de 1945 y romper el mito imperante.

Aunque los hallazgos presentados no eran nuevos para los historiadores, éstos aún no habían entrado en la conciencia popular. Poco a poco fueron completados con nuevas aportaciones, produciendo documentos que además sostenían el papel activo jugado por el ejército en los crímenes. Rápidamente se demostró que la leyenda de la Webrmacht aún estaba muy patente en la sociedad alemana y la ruptura de ese tabú no se produjo de forma abrupta, sino que fue más bien el despliegue de un proceso.

Dos factores contribuyeron especialmente al éxito de la exposición. Primero, contrariamente a todas las expectativas, la mayoría de los visitantes no representaban la generación de 35-50 años (con una memoria de "segunda mano" de la guerra), sino de los más jóvenes (16-30, sin apenas referentes) y las generaciones más viejas (que habían experimentado la guerra de primera mano) (Ulrich, 1998). El segundo factor fueron las controversias políticas que surgieron como resultado del éxito sin precedentes de la exposición. Aunque la primera fase de su recorrido había creado un cierto debate público a nivel local y regional, su llegada a Múnich marcó un punto de inflexión y el inicio del debate nacional. No sólo fue una novedad en sí mismo, sino que también demostraba las emociones que habían surgido a partir de la exposición, y se transformó en un intercambio ritual de argumentos a favor y en contra, en un foro de discusión también para las memorias personales de los políticos, que se extendió a raíz del debate en el Bundestag sobre este tema, en marzo de 1997. Expresaban los recelos sobre la generación de los crímenes y el consiguiente colapso total del mito sobre la Wehrmacht (Rosenthal, 1998: 121).

La exposición se convirtió en un debate sobre los posibles lazos entre los crímenes y el padre, abuelo, tío o hermano. Y así, las personas que la visitaban buscaban entre las fotografías

9 Aunque el Bundeswehr ya no la usa como medalla, una representación de la Cruz de Hierro está en su emblema oficial. 
los rostros de sus familiares. Considerando que diez millones de alemanes sirvieron como soldados activos en el Frente del Este y que sólo se mostraba un millar de fotos, se trataba de una búsqueda inútil.

A pesar de que gran parte de las controversias que surgieron hacían referencia a las fotos, era mucho más que una exposición fotográfica: ante todo presentaba textos y documentos, descripciones de los hechos, órdenes, cartas de los soldados, informes de las autoridades, etc., que daban veracidad a las imágenes. Las fotos servían para ilustrar lo que los textos documentaban, desde las perspectivas propias de los soldados. Y esto era lo más perturbador (Heer, 2002). Los soldados fotografiaron una gran cantidad de hechos: algunos querían documentarlos, conscientes de que eran crímenes; la fascinación llevó a otros a fotografiar lo extraño, lo cruel; otros, simplemente, buscaban un recuerdo de su "viaje" a Rusia. Sin embargo, algunos de ellos -y las notas de las fotos lo demuestran - tomaron imágenes que consideraban interesante llevarse a casa, como recuerdos o trofeos de sus "hazañas". La exposición forzaba a los visitantes a observar a través de los ojos de los testigos y, en ocasiones, a través de ojos que están observando lo que sucede de forma aprobadora, o incluso de los perpetradores.

Las fotografías fueron casi tan impactantes como las películas de los Aliados durante la liberación de los campos de concentración, porque estaban tomadas inmediatamente antes, durante y después del crimen y mostraban a las víctimas en relación directa y visible con los verdugos, a diferencia de la distancia de las imágenes típicas de los campos, tomadas siempre a posteriori. Muchas fotos no se habían mostrado nunca, y eso les confirió un aura de descubrimiento súbito y de evidencia criminal (de Toro, 2011). Además, la presencia directa de los soldados en el escenario del crimen, algo que no se había visto hasta entonces, impactaba directamente a la sociedad.

El texto, la documentación, se volvió redundante, porque las fotos parecían capturar los momentos esenciales en una secuencia no encadenada. Eran contundentes por lo que implicaban sobre los fotógrafos y porque el observador era animado a compartir su perspectiva: estaban participando visualmente, igual que los soldados. Simbolizaba la posición del observador y mostraba cuestiones como la complicidad moral de aquellos que habían sido testigos de la brutalidad, junto a los perpetradores.

Otra de las fuentes de debate fue el título mismo de la exposición: el término Vernichtungskerieg (guerra de aniquilación) fue escogido para enfatizar que se refería a un tipo especial de guerra; el subtítulo Verbrechen der Wehrmacht (crímenes de la Wehrmacht) fue situado conscientemente en una posición subordinada, intentando dirigir la atención a la categorización legal de este tipo de guerra. Pero desde el principio los medios de comunicación escribieron sobre la Wehrmachtsausstellung, evitando así la polémica sobre el título y la generalización (Klotz, 2001: 117).

El papel expuesto de la Wehrmacht en la guerra tuvo otra consecuencia política importante, porque llegaba en un momento en que el gobierno federal y el Bundeswehr estaban preparándose para participar en una acción militar en los Balcanes, la primera acción internacional tras la Segunda Guerra Mundial. Por tanto, había razones contemporáneas que presionaban para defender la leyenda de la Wehrmacht. 
El tema de los crímenes comenzó a circular en público abiertamente, mientras en el ámbito familiar apenas si llegaba a hacerlo: padres o abuelos apenas discutían detalles de sus actividades durante la guerra. Y en la medida en que esas discusiones tenían lugar, los lazos de lealtad dentro de la familia a menudo impulsaban a los más jóvenes a reinterpretar lo que oían para proteger a sus familiares (Welzer, 2002: 150-156). Ahora, cada visitante encontraba en la exposición nociones sobre el papel que su familia podría haber jugado antes y durante la guerra, un conocimiento que antes les había sido negado.

Welzer ha explorado cómo la segunda y tercera generaciones de alemanes percibían a los miembros de su familia que vivieron la guerra. Los autores de este trabajo señalan que la comunidad de memoria de la familia es diferente de la más amplia memoria cultural. Los nietos de aquellos que vivieron los hechos tienden a pensar que sus abuelos fueron héroes o víctimas y en su mayor parte rechaza concebirlos como parte de los perpetradores de la guerra. Plantean que las memorias "siempre [implican] la reinscripción" (Welzer et al., 2002: 344). Este proceso puede alterar la memoria de un hecho que consiste tanto en la memoria del hecho mismo como su recuerdo, que no pueden verse separadamente.

Mientras las generaciones alemanas de postguerra han sido educadas sobre el Holocausto y el Nazismo, a menudo tienden a insistir que sus padres y abuelos no podían haber sido perpetradores. El recuerdo mantiene coherente la identidad del grupo, pero esta identidad se ve amenazada cuando surgen nuevas memorias. Por ejemplo, cuando se demuestra que un miembro de la familia fue un nazi.

Su estudio también señala la aparente contradicción del reconocimiento de las generaciones de postguerra, a través de la memoria cultural, de que la generación de sus padres y abuelos fueron perpetradores, pero a través de la memoria familiar rechazan reconocer esto cuando se refiere a su propia familia.

En el proceso se hizo evidente el enorme significado del Tercer Reich, la guerra y el genocidio para la autocomprensión de los alemanes, como demostraban las conmemoraciones de 1995 y los temas que remarcaban los medios de comunicación: la liberación de los campos, los bombardeos Aliados, los refugiados que huían del Este, los últimos días de la guerra y la rendición incondicional, pero no los crímenes de la Wehrmacht.

Los descubrimientos de la exposición eran sólo la punta del iceberg, pero indicaban que era necesaria una mayor investigación en archivos anteriormente inaccesibles, que proporcionarían más indicios sobre ese oscuro episodio de la historia.

\section{CRÍTICAS A LA EXPOSICIÓN}

Más que facilitar el diálogo intergeneracional, los organizadores provocaron una actitud defensiva en los Zeitzengen (testigos directos). La exposición fracasó a la hora de describir el marco histórico en el que la Wehrmacht y sus miembros se encontraban: no contextualizaba el ámbito bélico, no ofrecía explicaciones sobre las situaciones descritas, no proporcionaba un trasfondo sobre las mentalidades del período y, principalmente, no mencionaba a la resistencia del 20 de julio de 1944 (que hasta entonces había servido como "coartada" para el conjunto de la población y el ejército) en ningún momento. Los críticos lamentaban los efectos de las fotos que, 
aunque eran evidencias abrumadoras, sin la adecuada contextualización histórica, "dejan al visitante sólo con el efecto emocional de las imágenes". Otros señalaban que no se tenía en cuenta que los soldados vivían en un sistema totalitario y temían por sus vidas, ni que la mentalidad general del período entendía la guerra contra la URSS como un conflicto de ideologías mundiales, de la que únicamente un bando podía emerger victorioso (Thiele, 1997: 68-69, 104-106, 119-120).

La exposición también fracasaba al explicar la continuidad ideológica entre la Wehrmacht y el Bundeswehr, ya que muchos antiguos miembros de la primera fueron esenciales en la construcción del segundo durante su fundación y primera fase de existencia. Pero el contexto mismo de la exposición llevó a una reacción negativa del Bundeswehr, que prohibió a sus miembros visitarla o asistir a actos relacionados vistiendo el uniforme.

Aunque durante mucho tiempo los historiadores no prestaron mucha atención a la exposición, la controversia desarrollada hasta 1999 atrajo la atención de algunos, que comenzaron a atacarla, con críticas que se centraron principalmente a la autenticidad de las fotos. Musial y Ungváry alegaron que una gran parte de las mismas estaba mal contextualizada y no describía crímenes cometidos por la Wehrmacht, sino atrocidades del Ejército Rojo o los partisanos. Musial declaró que se había clasificado erróneamente nueve fotografías; mientras Ungváry publicó un "análisis cuantitativo y cualitativo" del material fotográfico, aunque sin presentar ningún tipo de prueba, señalando simplemente que el $90 \%$ de las fotos no mostraba crímenes de la Webrmacht. Ungváry afirmaba también que el "combate normal" contra partisanos y otros grupos de resistencia civil no constituía un crimen (Musial, 1999: 563-591; Ungváry, 1999: 584-595).

Los organizadores de la exposición, a pesar de todo, habían superado muchos de los problemas metodológicos del trabajo con fotografías, pero las habían dejado expuestas a serias críticas académicas: en ocasiones, las fuentes no estaban especificadas de forma precisa; sus localizaciones eran vagas; el hecho inmediato quedaba sin aclarar, etc. A pesar de todo, aunque las fotografías podían ser inexactas y algunos crímenes asignados a los perpetradores erróneos, era un material que mantenía su carácter de evidencia.

Metodológicamente, la incorrecta atribución es un problema común cuando se trabaja con material fotográfico, debido al secretismo con que muchas de esas fotografías fueron tomadas, que los fotógrafos a menudo no las databan ni localizaban, que llegaban a archivos a través de rutas muy complejas, etc. Ya que la tesis presentada por la exposición era tan dependiente del material fotográfico, la fiabilidad de las fotos como evidencia precisa era un tema importante para los críticos, que también habían puesto de relieve la necesidad de aplicar métodos mucho más precisos con ese material.

A pesar de que el puñado de fotos que Musial consideraba erróneas (nueve de un total de 1.400) no podía alterar materialmente el peso de los resultados del proyecto de investigación, se inició una maliciosa campaña contra la exposición y sus tesis principales (Musial, 1999: 582). Las críticas se centraban también en la falta de elementos metodológicos y didácticos para entender las imágenes que se mostraban, porque producían conmoción y horror, pero dejaban al espectador con preguntas de fondo. Por eso, también las organizaciones de veteranos de guerra negaron y se opusieron a la exposición. 
Frente a tales ataques Heer y sus colaboradores rechazaron, al principio, reconocer o examinar el trasfondo de las críticas. Esta pasividad hizo más fácil para los críticos movilizar a los medios de comunicación, que se apresuraron, de una conferencia de prensa a otra, y esperaban que la exposición fuese finalmente clausurada y Heer despedido. Finalmente, Reemtsma cedió a la presión y en noviembre de 1999 anunció la clausura temporal de la exposición hasta que una comisión de historiadores pudiese examinar las fotografías. El pretexto específico para el cierre de la exposición (unos pocos títulos de fotos incorrectos) fue atribuido a la falta de atención a la hora de enlazar las fotos con eventos históricos específicos, un error metodológico derivado de tratar con material fotográfico.

Los críticos procedían principalmente de los sectores más conservadores y señalaban que la exposición daba la impresión de que la Wehrmacht, como conjunto, era una organización criminal y difamaba el honor de aquellos que habían servido a su país. La prensa conservadora, como el Frankfurter Allgemeine Zeitung, señalaba que toda la exposición había sido instrumentalizada por sectores de la izquierda política para defender sus objetivos políticos e ideológicos. La acusación de que sólo una pequeña parte de las fotos mostraba actos criminales de la Wehrmacht no señalaba nada, a menos que se quisiera leer la evidencia a través de un filtro ideológico, pero servía para condenar la exposición.

En el ámbito político, los partidos más conservadores (CSU y CDU) y los sectores de extrema derecha (Republikaner y NDP) intentaron bloquear cualquier apoyo oficial a la exposición, organizando eventos "alternativos" o exposiciones diseñadas para contrarrestar su impacto. El rechazo de la CDU a la exposición se basaba en que la mayoría de los soldados no habían cometido crímenes y, por tanto, no negaban las evidencias, sino la extensión del crimen. Su temor era que el foco en los crímenes llevase a un cambio hacia un punto de vista más crítico de la Webrmacht y, por extensión, del Bundeswehr. Imputando a los organizadores una intención difamatoria buscaban persuadir al público en general de que la imagen que proyectaba era insultante, tendenciosa y premeditada. Consideraban que era partidista, porque excluía la historia del 20 de julio. Pero tendían hacia la total heroización de la Wehrmacht, argumento típico de la extrema derecha.

Por su parte, el SPD y, particularmente, Die Grüne, dudaban de que el Bundeswehr hubiese roto realmente con la tradición heredada de la Wehrmacht y estaban alarmados por los actos cada vez más numerosos de radicalismo de extrema derecha dentro del ejército.

Las imágenes transmitidas de la Webrmacht eran de gran importancia en el presente, y por eso era inevitable que la derecha buscase desacreditar la exposición, considerándola propaganda de izquierda. Por su parte, la izquierda desacreditaba la crítica de la derecha como propaganda de extrema derecha. El resultado de estos debates fue animar a más personas a visitar la exposición, mostrando su interés en el documento sobre la guerra de exterminio más extensa de la historia de la humanidad.

La retirada de la exposición sirvió al Hamburger Institut für Sozialforschung para que fuese analizada por una comisión independiente. Esto demostró ser una reacción efectiva a las críticas. En noviembre de 2000 se publicó el informe de conclusiones (Bartov, 2000a: 75-76), que señalaba que la exposición era tan necesaria como valiosa, y que continuaría siendo una contribución esencial al desarrollo de la cultura histórico-política en Alemania, aunque eran 
necesarios algunos cambios. Las críticas, de acuerdo con la comisión, eran parcialmente válidas: contenía algunos errores de atribución, era imprecisa en el uso del material y hacía afirmaciones demasiado generalizadas. Pero también señalaba que no se había falsificado el material, ni fotográfico ni textual, y que las falsas atribuciones eran síntoma de una falta de metodología de la historiografía al tratar con fuentes gráficas. Tampoco había dudas de que las tesis básicas de la exposición eran correctas: la Wehrmacht no fue meramente un elemento marginal del crimen en la Europa oriental, sino que había tomado parte activa en el crimen.

La comisión recomendaba, por tanto, que la exposición fuese corregida para incluir la perspectiva de las víctimas y revisada para adaptar los requerimientos de la metodología y el rigor historiográfico, y presentada nuevamente (Bartov, 2000a: 70).

A partir de estas conclusiones, el Hamburger Institut für Sozialforschung preparó un equipo totalmente diferente de jóvenes historiadores que crearía una exposición revisada. Si la primera se titulaba Vernichtungskrieg. Verbrechen des Webrmacht 1941 bis 1944 (Guerra de exterminio. Crímenes de la Webrmacht 1941 hasta 1944), la segunda se denominó Verbrechen der Wehrmacht. Dimensionen des Vernichtungskrieges 1941 bis 1944 (Delitos de la Wehrmacht. Dimensiones de la guerra de exterminio 1941 hasta 1944). Esta segunda versión, mucho menos controvertida que la primera, se reabrió en Berlín, en 2001. Se esforzaba por mantener una mayor distancia y objetividad y elaboraba más los textos que las imágenes, lo que llevó a que algunos la denominasen una "exposición de consenso". Ya en el mismo título dejaba patente su aspiración conciliadora, cuando el concepto de "guerra de exterminio" (Vernichtungskrieg) quedó relegado al subtítulo. También se eliminaron los aspectos más escandalosos de la original: por ejemplo, fueron "depuradas" las fotos tomadas por los soldados alemanes, o fotos de soldados sonrientes junto a sus víctimas, tanto antes como después de la ejecución.

La segunda exposición se concibió como una oportunidad para un debate científico sobre el estado de la investigación sobre la Webrmacht, y se convocó un coloquio patrocinado por el Hamburger Institut für Sozialforschung y el Institut für Zeitgescbichte, un encuentro que dio como resultado la publicación de un libro que proporcionaba una visión general de la investigación (Hartmann, Hürter y Jureit, 2005). Pero cuanto más intentaba presentarse la segunda exposición como "apolítica", más claro quedaba el significado político de las acciones de Reemtsma y del Hamburger Institut, sobre todo porque la clausura de la primera exposición no podía entenderse de otra forma que como una capitulación ante la casta política y militar dominante (Heer, 2002: 872).

Se añadían también otros dos aspectos: los actos de personas individuales y la percepción de las fuerzas armadas en el período de postguerra (Hamburger Institut für Sozialforschung, 2002: 13). También la proporción de documentos escritos y fotográficos cambió totalmente, y la participación del ejército en los crímenes se reflejaba más a través de los textos que de las imágenes (Juriet, 2004: 3-27), mejorando la contextualización del conjunto: el foco se apartaba un poco de los criminales hacia los lugares, tiempos, circunstancias y detalles de cada crimen.

Sin embargo, ciertos críticos señalaron que se mantenían algunos déficits: los crímenes en la campaña de Polonia, la participación en el genocidio de los gitanos, el papel de las organizaciones de auxiliares extranjeros, etc. En particular, se evitaba la cuestión de los motivos y actitudes de los soldados, que seguía sin respuesta. A pesar del "consenso" que aglutinaba esta 
segunda exposición, también en su presentación se llevaron a cabo manifestaciones y actos de extrema derecha y conservadores. Pero, a diferencia de la primera, las críticas fueron menos intensas: por ejemplo, el Ministerio de Defensa permitió a oficiales y soldados participar de uniforme en los eventos relacionados con la misma.

\section{REFLEXIONES FINALES}

¿Cómo pudo mantenerse el papel de la Wehrmacht durante el Nazismo como un tabú durante tanto tiempo y, al mismo tiempo, flotar justo por debajo de la superficie de la memoria, esperando para convertirse en un objeto de debate público?

Durante la mayor parte de la historia de la postguerra, los miembros de la Webrmacht fueron considerados como una de las principales víctimas de la locura de Hitler, mientras que los potenciales lazos entre militares y Holocausto fueron invisibles o quedaron "minimizados", aunque el genocidio había entrado en la conciencia pública masivamente a mediados de los 1970.

Tras la guerra, el Holocausto había sido un "símbolo del mal" y la responsabilidad había sido atribuida a los nazis, excluyendo a los civiles. Por eso, la participación del ejército en el Holocausto eliminaba tal distinción e indicaba que todos los alemanes habían estado involucrados en algún tipo de crimen.

El esquema esencial de lo que sucedió en la "guerra de aniquilación" en el Este ha sido confirmado por historiadores alemanes e internacionales, aunque aún es necesaria más investigación (Müller y Volkmann, 1999). Las nuevas generaciones están en proceso de examen y evaluación de las nuevas fuentes materiales que no sólo nos permiten comprender mejor las diferencias regionales que existían a la hora de llevar a cabo las políticas de exterminio, sino que también nos proporcionarán una imagen de cómo se produjo el proceso de asesinato.

La exposición, como otras controversias historiográficas, revelaba los problemas para "asumir el pasado" e indicaba que la sociedad alemana que se había adherido a la "negación del crimen colectivo" estaba ahora en una situación en la que debían enfrentarse directamente al pasado como el problema de su propia sociedad. Realmente explica lo difícil que es enfrentarse al hecho de que muchos alemanes estuviesen involucrados en el Holocausto. Pero el debate es altamente revelador, porque nos muestra las dificultades que enfrentan en todo lo que hace referencia al Holocausto (Schoeps, 1996).

A pesar de todos los progresos realizados en los estudios sobre la Wehrmacht, la historiografía aún adolece de grandes lagunas sobre el papel de perpetradores de los militares alemanes. Aunque se han dado los primeros pasos para luchar contra este vacío, el análisis del papel del ejército en el proceso de exterminio aún está en sus inicios. Por supuesto, aún hay espacio para debatir la cuestión de si la Wehrmacht, como tal, fue una organización criminal o genocida, aunque su participación, a gran escala, en los crímenes parece ya fuera de toda duda. El problema que queda por resolver no es la documentación o el tratamiento de las evidencias, sino que lo que persiste es un problema de percepción, recepción, metodología y prejuicios, tanto políticos como ideológicos o nacionales.

La reunificación abrió la posibilidad de proyección de una imagen más inclusiva del pasado nazi en el ámbito público, lo que provocó, a su vez, una creciente conciencia por parte de los 
alemanes de la auténtica extensión y naturaleza de los crímenes. Pero llevó también a una creciente comprensión del concepto de "perpetrador", ya que el grado de participación de los soldados "ordinarios" era aún mayor, como se comprende ahora, de lo que se había asumido durante mucho tiempo. Igualmente se ha incrementado el abanico de víctimas reconocidas como tales, que ha hecho cambiar la noción de victimización, con una menor inclinación a colorear el sufrimiento de los expulsados o las víctimas alemanas de los bombardeos aéreos por encima de otras víctimas, porque no son sólo los "soldados ordinarios" los que tienen que enfrentarse al pasado, sino también los "ciudadanos ordinarios" o las empresas alemanas. Como señala Niven: "La contribución de Alemania a esta reconciliación, además, va más allá del pago y la compensación"10 (Niven, 2002: 230). La Webrmachtsausstellung abrió nuevas líneas de investigación para los historiadores: la mentalidad entre los soldados (algo que anteriormente había sido obviado), nuevas fuentes materiales (como las cartas enviadas desde el frente), los motivos de los perpetradores, etc.

En general, no se podría apreciar el papel de la controversia sobre la Webrmachtsausstellung, dentro del proceso de reconocimiento alemán del pasado nazi sin analizar también temas de memoria personal y colectiva, que la exposición ponía de manifiesto. Si bien es cierto que los aspectos políticos y públicos de la controversia tuvieron un profundo impacto en la identidad nacional de la Alemania recién unificada, los aspectos personales y sociales a examinar pueden mostrarnos algo importante para la transmisión de la conciencia histórica, de generación en generación.

La controversia demostró, una vez más, que el pasado "no ha pasado", como Nolte había deseado durante la Historikerstreit. También que el pasado no debe someterse a procesos de "normalización", como el que el Canciller Helmut Kohl había planteado en la controversia de la Neue Wache (de Toro, 2015: 203-229). Las memorias del pasado, tras la reunificación, han experimentado cambios en relación a las grandes transformaciones políticas, sociales y generacionales. Cuando los últimos Zeitrengen desaparezcan, es probable que la conciencia histórica continúe cambiando, un proceso para el que Martin Broszat acuñó el término Historisierung (historización) durante la Historikerstreit, y que los historiadores han debatido desde entonces (Broszat, 1990: 77-87).

Pero a pesar de la inevitable historización que llega con el paso del tiempo, el Nazismo y el Holocausto no se han convertido en una historia como otra cualquiera. Aprender, hablar y debatir sobre el legado del pasado nazi se ha convertido en un aspecto normal y regular de la vida política alemana, igual que la conmemoración se ha convertido en parte del paisaje de la memoria social de la nación.

La investigación sobre la identidad social de los perpetradores se acaba de iniciar, pero las narrativas están desarrollándose de forma similar a la del Holocausto a mediados de los 1970. Los debates sobre la exposición comenzaron a derramarse por otros contextos, cambiando los límites de la matriz cultural, lo que permite afirmar, desde la perspectiva que da el tiempo, que la leyenda de las "manos limpias" de la Wehrmacht ahora ya pertenece al pasado.

\footnotetext{
10 Traducción del autor.
} 


\section{BIBLIOGRAFÍA}

ABEnHEIM, Donald (1988). Reforging the Iron Cross: the search of tradition in the West German Armed Forces. Princeton: Princeton University Press.

BARTOV, Omer (1985). The Eastern Front, 1941-1945: German troops and the barbarization of warfare. Londres: Palgrave Macmillan.

BARTOV, Omer (1991). Hitler's Army: soldiers, Nazis and war in the Third Reich. Oxford: Oxford University Press.

BARTOV, Omer (1994). “The Missing Years: German Workers, German Soldiers”. Crew, David (ed.). Nazism and German Society 1933-1945. Londres: Routledge: 41-66.

BARTOV, Omer (1996). "Historians on the Eastern Front: Andreas Hillgruber and Germany's Tragedy". Bartov, Omer (ed.). Murder in Our Midst: The Holocaust, Industrial Killing, and Representation. New York: Oxford University Press: 71-88.

BARTOV, Omer (1999). "Professional soldiers". Hamburg Institute For Social Research (ed.). The German Army and genocide: crimes against war prisoners, Jews, and other civilians, 1939-1944. Nueva York: New Press: 10-17.

BARTOV, Omer et al. (2000a). Bericht der Kommission zur Überprïfung der Austellung 'Vernichtungskerieg. Verbrechen der Webrmacht 1941 bis 1944'.

BARTOV, Omer (2000b). "German soldiers and the Holocaust. Historiography, research and implications". Bartov, Omer (ed.). The Holocaust. Origins, implementation, aftermath. Nueva York: Routledge: 162-185.

BARTOV, Omer (2000c). “Whose History is it, anyway?": the Wehrmacht and German Historiography”. Heer, Hannes y Naumann, Klaus (eds.). War of extermination: the German military in World War II, 1941-1944. Oxford: Berghahn Books: 400-416.

BAuM, Steven K. (2008). The psychology of genocide: perpetrators, bystanders and rescuers. Cambridge: Cambridge University Press.

BergmanN, Klaus y Schörcken, Rolf (eds.) (1982). Geschicbte im Alltag-Alltag in der Geschichte. Düsseldorf: Patmos Verlag.

BORGSTEDT, Angela (2009). "Die kompromittierte Gesellschaft. Entnazifizierung und Integration”. Reichel, Peter; Schmid, Harald y Steinbach, Peter (eds.). Nationalsozialismus die zwweite Geschichte: Überwindung, Deutung, Erinnerung. Múnich: C.H. Beck: 85-105.

Broszat, Martin (1990). "A Plea for the Historicization of National Socialism". Baldwin, Peter (ed.). Reworking the Past: Hitler, the Holocaust, and the Historians' Debate. Boston: Beacon Press: 77-87.

Broszat, Martin (ed.) (1998). Kommandant in Auschwitz: Autobiographische Aufzeichnungen des Rudolf Höß. Múnich: dtv Verlagsgesellschaft.

BroszAt, Martin y Fröhlich, Elke (1987). Alltag und Widerstand: Bayern im Nationalsozialismus. Múnich: Piper. 
BrownIng, Christopher R. (1993). Ordinary men. Reserve Police Battailion 101 and the Final Solution in Poland. Nueva York: Harper Perennial.

De Toro, F. Miguel. "Historia social de la resistencia alemana al nazismo". Historia Social 26 (1996): 129-140.

De Toro, F. Miguel. "La memoria del Holocausto en Alemania: la memoria dividida". Historia Social 65 (2009): 87-106.

DE TORO, F. Miguel. "La fotografía como evidencia. La representación gráfica y la construcción de la memoria colectiva del Holocausto". Ponencia presentada en el Congrés Internacional 'Espai urbà, memòria i ciutadania'. Barcelona, 2011.

De Toro, F. Miguel. "Políticas de memorialización y victimización en Alemania: la Neue Wache y el espacio memorial (1870-1993)". Ayer 100 (2015): 203-229.

DE TORO, F. Miguel. "Denkmal für die ermordeten Juden Europas y el paisaje de la memoria en la Alemania reunificada". Pasado y Memoria. Revista de Historia Contemporánea 15 (2016): 281-305.

DiNer, Dan (1988). Zivilisationsbruch: Denken nach Auschwit:. Frankfurt am Main: Fischer Taschenbuch.

Evans, Richard (1989). In Hitler's Shadow: West German Historians and the Attempt to Escape from the Nazi Past. Nueva York: Alfred a Knopf.

FEHRENBACH, Heide (1995). Cinema in democratizing Germany: reconstructing national identity after Hitler. Chapel Hill: The University of North Carolina Press.

FOCKE, Harald y Strocka, Monika (1985). Alltag der Gleichgeschalteten: Wie die Nazis Kirche, Kultur, Justiz und Presse braun färbten. Rowohlt: Reinbeck bei Hamburg.

FREI, Norbert (2002). Adenauer's Germany and the Nazi past: the politics of amnesty and integration. Nueva York: Columbia University Press.

Friedlander, Henry (1983). “The Perpetrators". Grobman, Alex y Landes, Daniel (eds.). Genocide: critical issues of the Holocaust. Los Angeles: Simon Wiesenthal Center: 155-158.

Goldhagen, Daniel J. (1996). Hitler's willing executioners: ordinary Germans and the Holocaust. Nueva York: Vintage.

Grossman, Atina (2000). "The 'Goldhagen effect': memory, repetition and responsibility in the new Germany". Eley, Geoffrey (ed.). The Goldhagen effect. Ann Arbor: The University of Michigan Press: 89-129.

HAmburger Institut Für SOZIALFOrschung (ed.) (1999). Eine Ausstellung und Ibre Folgen zur Rezeption der Ausstellung "Vernichtungskrieg. Verbrechen der Webrmacht 1941-1944”. Hamburgo: Hamburger Edition.

HAMbURger InStITUT FÜr SOZIALFORSCHUNG (ed.) (2002). Verbrechen der Webrmacht. Dimensionen des Vernichtungskrieges 1941-1944. Ausstellungskatalog. Hamburgo: Hamburger Edition. 
HARTMAnN, C.; Hürter, J. y Jureit, U. (eds.) (2005). Verbrechen der Wehrmacht: Bilanz einer Debatte. Múnich: C.H.Beck.

HeER, H. 'Vom Verschwinden der Täter. Die Auseinandersetzung um die Ausstellung "Vernichtungskrieg. Verbrechen der Wehrmacht 1941 bis 1944"'. Zeitschrift für Geschichtswissenschaft 50 (2002): 869-898.

Hillgruber, Andreas (1985). "Der geschichtliche Ort der Judenvernichtung: Eine Zusammengassung". Jackel, Eberhard y Rohwer, Jürgen (eds.). Der Mord an den Juden im Zweiten Weltkrieg. Frankfurt: Deutsche Verlags-Anstalt: 213-224.

Hillgruber, Andreas (1986). Zweierlei Untergang: Die Zerschlagung des deutschen Reiches und das Ende des europäischen Judentums. Berlín: Siedler Verlag.

JACOBSEN, Hans-Adolf (1965). "Kommissarbefehl und Massenexekutionen sowjetische Kriegsgefangener”. Buchheim, Hans et al. (eds.). Anatomie des SS-Staates. Olten: Deutscher Taschenbuch Verlag: 170-182.

JASPERS, Karl (1979). Die Schuldfrage. Für Völkermord gibt es keine Verjäbrung. Múnich: Piper.

JURIET, Ulrike: “'Zeigen heißt verschweigen'. Die Ausstellungen über die Verbrechen der Wehrmacht". Mittelweg 36 (2004): 3-27.

Kershaw, Ian (1983). Popular Opinion and Political Dissent in the Third Reich: Bavaria 1933-1945. Oxford: Oxford University Press.

KLOTZ, J. (2001). "Die Ausstellung 'Vernichtungskrieg. Verbrechen der Wehrmacht 1941 bis 1944' Zwischen Geschichtswissenschaft und Geschichtspolitik”. Bald, D. et al. (eds.). Mythos Wehrmacht Nachkriegsdebatten und Traditionspflege. Berlín: Aufbau Taschenbuch Verlag: 116-176.

KNÄPplE, L. (2009). "Wehrmachtsausstellung". Fischer, Torben y Lorenz, Matthias (eds.). Lexikon der 'Vergangenheitsbewältigung'. Berlín: Transcript: 288-290.

KrausniCK, Helmut y Wilhelm, Hans-Heinrich (1981). Die Truppe des Weltanschaunngskrieges: Die Einsatzgruppen der Sicherheitspolizei und des SD, 1938-1942. Stuttgart: Deutsche Verlags-Anstalt.

KROENER, Berhard R. (1990). "Auf dem Weg zu einer 'nationalsozialistischen Volksarmee". Broszat, Martin; Henke, Klaus-Dietmar y Woller, Hans (eds.). Von Stalingrad zur Wehrungsreform: Zur Sozialgeschichte des Umbruchs in Deutschland. Múnich: Oldenbourg: 651-682.

KWIET, Konrad (2001). "Perpetrators and the Final Solution”. McMahon-Kaye, Stephanie (ed.). The memory of the Holocaust in the 21st Century: The challenge for education. Jerusalén: Yad Vashem: 61-82.

LARGE, David C. (1996). Germans to the Front: West German rearmament in the Adenauer Era. Chapel Hill: The University of North Carolina Press.

LONGERICH, Peter. "Tendenzen und Perspektiven der Täterforschung". Aus Politik und Zeitgeschichte 14-15 (2007): 3-7. 
LÜDTKE, Alf (ed.) (1965). The History of Everyday Life: Reconstructing Historical Experience and Ways of Life. Princeton: Princeton University Press.

MAIER, Charles S. (1988). The Unmasterable Past: History, Holocaust, and German National Identity. Cambridge: Cambridge University Press.

MANOSCHEK, Walter (ed.) (1995). "Es gibt nur eines für das Judentum: Vernichtung": Das Judenbild in deutschen Soldatenbriefen 1939-1945. Hamburgo: Hamburger Edition.

MANOSCHEK, Walter. "'Vernichtungskrieg. Verbrechen der Wehrmacht 1941-1944'. Innenansichten einer Ausstellung”. Zeitgeschichte 29 (2002): 64-75.

MEIER, Christian (2001). Das Verschwingen der Gegenwart. Múnich: Carl Hanser Verlag.

MesserschmidT, Manfred (1969). Die Wehrmacht im NS-Staat: Zeit der Indoktrination. Hamburgo: Deckers Verlag.

MichalkA, Wolfgang (ed.) (1989). Der Zweite Weltkrieg: Analysen, Grundヶüge, Forschungsbilanz: Múnich: Piper.

Militargeschichtliches Forschungsmat (ed.) (1990). Germany and the Second World War. Nueva York: Oxford University Press.

MüLLER, Rolf-Dieter y Volkmann, Hans-Erich (ed.) (1999). Die Wehrmacht: Mythos und Realität. Múnich: Oldenbourg.

MusIAL, Bodgan. "Bilder einer Ausstellung - Kritische Anmerkungen zur Wandernausstellung”. Vierteljahreshefte für Zeitgeschichte 47 (1999): 563-591.

NAIMARK, Norman. "War and genocide on the Eastern Front, 1941-1945". Contemporarny European History 16: 259-274.

Niven, Bill (2002). Facing the Nari past. United Germany and the legacy of the Third Reich. Londres: Routledge.

PAUL, Gerhard (2002). "Von Psychopathen, Technokraten des Terrors und 'ganz gewöhnlichen' Deutschen: Die Täter der Shoah im Spiegel der Forschung”. Paul, Gerhard (ed.). Die Täter der Shoab: Fanatische Nationalsozialisten oder ganz, normale Deutsche? Göttingen: Wallstein Verlag: 13-92.

Rosenthal, G. (1998). “Die Kinder des 'Dritten Reiches'. Sozialisiert im familialen Rechtfertigungsdialog". Hamburger Institut für Sozialforschung (ed.). Besucher einer Ausstellung: Die Austellung "Vernichtungskrieg und Verbrechen der Webrmacht 1941-1944" in Interview und Gespräch. Hamburgo: Hamburger Edition: 116-140.

SchoEPS, Julius (ed.) (1996). Ein Volk von Mördern? Die Dokumentation zur Goldhagen-Kontroverse um die Rolle der Deutschen im Holocaust. Hamburg: Hoffmann und Campe.

SERENY, Gitta (2009). Desde aquella oscuridad: conversaciones con el verdugo: Franz Stangl, comandante de Treblinka. Barcelona: Edhasa.

STREIM, Alfred (1981). Die Behandlung sowjetischer Kriegsgefangener im "Fall Barbarossa". Ein Dokumentation. Heidelberg: C.F. Müller Juristischer Verlag. 
STREIT, Christian (1978). Keine Kameraden: Die Wehrmacht und die sowjetischen Kriegsgefangenen, 1941-1945. Stuttgart: Dietz.

Thiele, H. G. (ed.) (1997). Die Wehrmachtsausstellung: Dokumentation einer Kontroverse. Bremen: Edition Temmen.

Ueberschar, Gerd R. (1995). "Der Mord an den Juden und der Ostkrieg: Zum Forschungsstand über den Holocaust". Lichtenstein, Heiner y Romberg, Otto R. (ed.). Tater - Opfer - Folgen: Der Holocaust in Geschichte und Gegenwart. Bonn: Bundeszentrale für Politische Bildung: 49-81.

UlRICH, B. (1998). Besucher einer Ausstellung: Die Ausstellung "Vernichtungskrieg. Verbrechen der Wehrmacht 1941-1944” in Interview und Gespräch. Hamburgo: Hamburger Edition.

UngVÁRY, Chrisztián. "Echte Bilder - problematische Aussagen. Eine quantitative und qualitative Fotoanalyse der Ausstellung "Vernichtungskrieg. Verbrechen der Wehrmacht 1941-1944". Geschichte in Wissenschaft und Unterricht 10 (1999): 584-595.

WALLER, James E. (2002). Becoming Evil: How ordinary people commit genocide and mass killing. Oxford: Oxford University Press.

Wegner, Bernd (ed.) (1997). From peace to war: Germany, Soviet Russia, and the World, 1939-1941. Providence: Berghahn Books.

Welzer, Harald et al. (2002). "Opa war kein Nazi": Nationalsozialismus und Holocaust im Familiengedächtnis. Frankfurt am Main: Fischer.

WETTE, Wolfram (ed.) (1992). Der Krieg des kleinen Mannes: Fine Militärgescbichte von unten. Múnich: Piper.

WETTE, Wolfram (1998). "Wehrmachtstraditionen und Bundeswehr: Deutsche Machtphantasien im Zeichen der neuen Militärpolitik und des Rechtsradikalismus". Klotz, J. (ed.). Vorbild Wehrmacht? Wehrmachtsverbrechen, Rechtsextremismus und Bundeswehr. Colonia: PapyRossa: 126-154.

WETTE, Wolfram y Ueberschar, Gerd R. (eds.) (1992). Stalingrad: Mythos und Wirklichkeit einer Schlacht. Frankfurt am Main: Fischer Taschenbuch Verlag.

Wieviorka, Annette (1998). L'Ėre du Témoin. París: Plon.

Young, James E. (1993). The structure of memory: Holocaust memorials and meaning. New Haven: Yale University Press. 